\title{
THEORIES OF POLICE LEGITIMACY - ITS SOURCES AND EFFECTS ${ }^{1}$
}

\author{
PAVLA HOMOLOVÁ \\ Department of Sociology, Faculty of Arts, Charles University \\ E-mail: homolova.pavla@centrum.cz
}

\begin{abstract}
The review of theories on police legitimacy aims at introducing the subject with a multidisciplinary approach. It quotes criminological, sociological as well as psychological and institutional theories of legitimacy, in order to provide the reader a rich framework, in which the findings of the presented current empirical studies can be evaluated. Police legitimacy is conceived as a social phenomenon, closely related to social norms such as socially constructed police roles and models of policing. The prevailing normative model of police legitimacy in criminology is discussed in greater detail, including critical outlook on procedural fairness as the assumed main source of police empirical legitimacy. Recent findings concerning legal socialization and theories of legitimization myths are highlighted in order to supplement the micro-level oriented criminological literature on police legitimacy. Possible future pathways of legitimacy research in criminology are discussed. Key words: police; legitimacy; trust; compliance; cooperation
\end{abstract}

\section{Introduction}

There exists no simple path toward police legitimacy. (Herbert, 2006, p. 497)

We live in an era when state institutions are closer to people than ever - former strict hierarchy of power has been in democracy abandoned in the name of principles of equality and public supervision. That places high demands on legitimization or justifying the power necessary for functioning of the institutions. Moreover, the institutions including the police are currently facing a difficult task of earning trust among citizens with various cultural backgrounds. Members of the current society have been socialized in very divergent socio-legal contexts and may carry different, even opposing normative images of what the police role is (on country-level divergencies in the expected police role see for instance Kutnjak Ivković et al., 2016). Given these factors, legitimization of the police cannot be taken for granted. We need to pay attention to general as well as context specific processes shaping police legitimacy in order to understand it. For a full apprehension of police legitimacy, it is also vital to consider its micro and macro aspects. The micro level is reflected in the notion of duality of legitimacy, suggested already by Weber (1972), more recently for instance by Bottoms and Tankebe (2012) and others (Suchman, 1995). In these accounts, legitimacy is conceived as a negotiated relationship between the governing institution and

1 The preparation of this journal article was supported by the Charles University funding scheme Progres Q15. 
the governed rather than a possession of the institution (Suchman, 1995). Besides, the police are not a stand-alone omnipotent institution (ibid.). To understand their power mechanisms, we should also take into consideration other macro level phenomenon, such as power based relations in the given society (see for instance Jauregui et al., 2013).

The normative, relational and contextual nature of police legitimacy signifies the relevance of the topic within social sciences such as sociology and criminology, notwithstanding law and criminal studies. The study focus lies in introducing the structure, correlates and consequences of police legitimacy based on a review of current largely criminological literature. We want to approach the theories of police legitimacy and legitimization with respect to the outlined social factors: norms, roles, relations and contexts or fields of power in Bourdieu's (1986) terminology. ${ }^{2}$ Even though the study does not allow for overly specific answers, we promote a theoretical framework that can serve more practical purposes of profound empirical exploration of police legitimacy in the future. According to modern normative political accounts, legitimacy resides in acceptance of a social responsibility to strive for a consensus (Clark, 2005, p. 192). Understanding the multiple processes may thus be seen useful in finding sources for a functional policepublic partnership in the globalized society. However, given the empirical approach to legitimacy in social sciences, we warn against treating the social science research on police legitimacy normatively.

\section{Empirical legitimacy}

Legitimacy is commonly understood as a justified use of power or authority. In social sciences we speak about empirical legitimacy - about justifications that are rooted in social definitions, without considering its objective criteria (following Weber, 1972). A renowned American theorist of organizations and sociologist Suchman defines legitimacy as a generalized perception or assumption that the actions of an entity are desirable, proper, or appropriate within some socially constructed system of norms, values, beliefs, and definitions (Suchman, 1995, p. 574). He makes it apparent that different sources of legitimacy are at play - not only desirability (instrumental reasons), ${ }^{3}$ but also appropriateness (normative reasons) and definitions (cognitive explanations). Equally importantly, Suchman (ibid.) underlines the socially constructed character of legitimacy. The social character of the legitimacy belief, stressed already by Weber (1972), means that legitimacy depends on a group belief, not just on single individual opinions (Suchman, 1995). American sociologist Lipset (1983, p. 64) offers another perspective of (political) legitimacy, which for him involves the capacity of a political system to engender and maintain the belief that existing political institutions are the most appropriate and proper ones for the society. The capacity to create such belief through (auto-) legitimizing mechanisms is undoubtedly inherent to any legitimate system, including the police. In contrast to Suchman's account,

2 We can no longer ask whether power comes from above or from below. Nor can we ask if the development and the transformation of the law are products of an evolution of mores toward rules, of collective practices toward juridical codification or, inversely, of juridical forms and formulations toward the practices which they inform. Rather, we must take account of the totality of objective relations between the juridical field and the field of power and, through it, the whole social field. (Bourdieu, 1986, p. 841)

3 For instrumental definition of legitimacy see for instance Cooper (2014). For him legitimacy is determined by a social acknowledgment of usefulness of a given organization for the society's well-being. 
in the Lipset's definition the core of legitimacy is seen in the governing system rather than the governed. Similarly, in conflict paradigm (see for instance Bourdieu, 1986, 1979) and cultural theories (Loader \& Mulcahy, 2003) the emphasis is put on power of the state and the police to symbolically influence the belief about what is considered as legitimate. The legitimacy belief that is part of both types of the outlined definitions is however generally apprehended as created from top-down as well as bottom-up, which points at the duality of legitimacy proposed earlier in this paper.

\section{Structure of empirical legitimacy}

Legitimacy is commonly divided in specific forms based on criteria used for its assessment. Distinguishing the forms is important because they may operate in divergent manner. The knowledge of the mechanisms and their structure is relevant not only in understanding legitimacy sources, but also in legitimacy management. The widely spread categorization concerning empirical legitimacy is that of normative versus instrumental legitimacy, depending on whether we stress values or needs/self-interest of the governed as the criteria for justification of the institution (Weigand, 2015). This dichotomy has been of large use within social sciences (including criminology), where the empirical notion of legitimacy prevails. Suchman (1995) adds another form, when he differentiates not only moral legitimacy (normative approval or evaluation whether the outputs, procedures and structures of the organizations are morally right) and pragmatic legitimacy (based on self-interest), but also cognitive legitimacy (based on cognitive comprehensibility, taken for grantedness). Cognitive legitimacy is connected to universal human needs for security and meaning. It can be further divided in comprehensible legitimacy (gained by meaningful, predictable organization's activities), and a deeper built-in taken for grantedness (when alternatives to that organization become unthinkable on the longterm), which is very hard to achieve. Together with the moral form of legitimacy, the cognitive legitimacy can be particularly useful for regulative institutions (e.g. in legal or educational subsystem) that are closely connected to norms - compared to technical organizations aimed primarily at effectiveness (Suchman, 1995).

Similar typology of empirical legitimacy is derived from the nature of obligation that is at the core of legitimacy. One may feel obliged to comply with the legitimate institution out of legal duty (regulative legitimacy expressed by perception "I have to"), out of moral duty (normative legitimacy expressed by "I ought to") or out of free consent (cognitive legitimacy expressed by "I want to") (Palthe, 2014). This division can be implicitly found in the prevailing model of police legitimacy (Jackson et al., 2016), even though the authors do not empirically distinguish between regulative and normative legitimacy. In their model, the former two dimensions can be found in obligation to obey (out of legal or moral duty) and the latter in sensation of police appropriateness (out of identification with the societal/police norms) (see the chapter Two facets of police legitimacy).

There are different strategies for maintaining each legitimacy type and the types have varied stability (Suchman, 1995). The cognitive type of legitimacy is the hardest to attain but at the same time the most stable (ibid.). The various forms of legitimacy can bolster each other but also impede each other. The stronger established the social order is, the lesser is the probability of conflicts arising among them (ibid.). 


\section{Police role and its implications for legitimacy}

\section{Consequences of police legitimacy}

Clark (2005) points out that legitimacy encourages or even enables certain types of behaviour while discourages other types. Behaviour is determined not only by people's actual wishes, but also by obligations. Perceived institutional legitimacy creates an obligation to behave in certain ways - e.g. defer to decisions of the institution. The relatedness of legitimacy and support for institutions in general is discussed in greater detail in the work of Suchman (1995). Legitimacy can lead to passive acceptance of the institutional agency as well as active assistance in reaching the goals of the institution. Earning active cooperation may however demand stronger legitimation practices because people may evaluate legitimacy more "stringently": To avoid questioning, an organization needs only 'make sense'. To mobilize affirmative commitments, however, it must also 'have value' (Suchman, 1995, p. 575). This could be roughly related to the above presented moral forms of legitimacy. Apart from the support, Suchman underscores also stability and credibility (or meaningfulness) of an organization as consequences of granted legitimacy. ${ }^{4}$ These two latter qualities are usually mutually reinforcing (ibid.). In political theory, Beetham (1991) pointed out the two-way relation between effectiveness and legitimacy not only effective institutions gain legitimacy, legitimacy also contributes to effective governing. Beetham's work on theory of legitimacy together with that of Coicaud and Curtis (2002) was later applied in criminological context (see chapter Legitimacy and normative model of compliance).

Consequences of perceived police (il)legitimacy have been widely discussed in the last years in criminology, constituting a prominent branch of policy. Tyler $(2004,2006 \mathrm{a})$ and others (Murphy, Bradford \& Jackson, 2016; Piquero et al., 2005; Reisig, Wolfe \& Holtfreter, 2011; Tankebe, 2013) showed that perceived police legitimacy brings support in the form of long-term compliance with the law and active cooperation on the side of the public. This is valid not only for general population, but also for criminal offenders (Papachristos, Meares \& Fagan, 2012; Reisig \& Meško, 2009). In total, not only legitimacy helps to multiply effectiveness of the police, it also empowers the relationship between the police and the communities that it serves. When people feel the police are legitimate, they identify with the police (and the society) more and it encourages them to participate on the police (societal) tasks (Tyler, 2006a). It seems that people who perceive the police more legitimate (as the monopolizing institution for rightful use of force) have also less tolerance to using private violence to deal with disputes, for self-protection or as a part of protest aiming at social change (Jackson et al., 2013). These results are extremely important for policy makers.

The reaction to perceived lack of beneficiality of an institution (under which we understand also lack of perceived legitimacy) on the other hand may exit (escape) or voice (protest) strategies on the side of the governed (Hirschman, 1970). These reactions can also be symbolic, one does not need to move out physically from the country to express

4 On the contrary, Clark (2005) does not see stability as a consequence of legitimacy, for him it is rather a correlate describing the same situation as legitimacy. 
their dissatisfaction with the police. It can be a more subtle way of escaping, for instance a "denial" in the form of ignoring police officers or an overall passivity towards the police, which is naturaly less risky than a full ignorance. The easier to exit, the lower probability of choosing the voice strategy (ibid.). The suggested escape through passivity does not demand any effort, and so may be a more comfortable (and also safer) way compared to protest against the police. It should be added that the choice of strategy will probably depend on reactions of other people in one's reference group. As Weber (1972) noted, when majority of people see the organization as legitimate, the rest will at least overtly comply to it due to social pressure. As Hirschmann (1970) also highlights, the two strategies do not exist pure in reality, usually we experience a certain ratio of both.

Overall it can be deduced that the more legitimacy the police have, the more active cooperation we can expect on the side of the public. This is very important given the dependence of the police success on active cooperation from people. In this way, legitimacy has gained attention in criminology as an important motive of human behaviour. Legitimate police can oblige people to comply with it: to defer to their decisions or to cooperate with them. But what does legitimate police mean?

\section{Models of legitimate policing}

... policing is a cultural text which communicates with a variety of social audiences and conveys an extended range of meanings. (Garland, 2001, p. 253)

The role of the police as ascribed by the state and perceived by the public is directly connected to police empirical legitimacy, be it crime detection, social welfare or law and order maintenance: Legitimacy is most readily acquired through a rational connection between what an organization does and what it achieves (Cooper, 2014, p. 2). ${ }^{5}$ Mawby (2012) distinguishes models of policing based on police function, police structure and source of police legitimacy. A control-dominated system is characterized by centralized police structure, crime control as the main aim and legitimacy derived usually from the state. It is built upon rational choice theory and as such it relies on instrumental incentives as the main motivations of compliance - usually sanctions or threats and reducing opportunities to commit crime (for instance through increased surveillance). In European context it existed in communist states, in the US it was popular within conservative criminal policies of the 1980s. Today it can be identified in hot-spots policing, strict policy of three strikes etc. (Trinkner \& Tyler, 2016).

The crime-control model is contrasting with the model of community policing (as a part of more general concept due process) being focused more upon social welfare and cooperative relationship with the authorities achieved through localized structure and legitimacy granted from local communities (Mawby, 2012). The community model is built upon assumption that norms and values can motivate compliance. The police that follow certain normative principles and share system of values with us can be trusted and legitimized to demand deference. The model originated in the 1960s in the US with attempts

5 This conception results from Weber's (1964) classical ideas of rationally (bureocratically) structured organizations. 
to bring the police closer to people as a part of civil rights protests and criticism of police brutality (Crank, 2003). Owing to the fact that people are motivated to compliance not only by norms, but also by gains and losses (for instance when calculating probability of being caught), policing will be probably most effective when combining both approaches. During democratization we can however expect an overall shift from control-dominated system towards community-oriented one, as the latter is closer to democratic ideals of policing (Mawby, 2012).

Each model of policing has its risks in terms of legitimization. In both cases the risks are partly related to overly strong expectations from the police, although in a different sense. The crime control model does not account for the fact that crime itself is influenced by many factors that are simply out of police reach. Moreover, it is hard to measure the real impact of certain policy on crime levels so the crime control can be evaluated and achieved only to limited extent (Cooper, 2014). Another problem is connected to the police tool for fighting crime - coercion by force is necessary but at the same time can be viewed as inappropriate, especially if it is used too often or too seldom (Kane, 2003). Manning (1978) adds, that even if the proper amount of coercion is used, it is usually not much effective for delivering the task. These all are aspects of what Manning calls the "impossible mandate" of the police. Not only does it complicate long term achievement of police legitimacy, it could also lead to a dysfunctional substitution of tools and targets and overestimation of crime fighting role of the police at the expense of other more important roles. If we accept that the main task of the police is to fight crime, there is only a few steps to a situation, where the police are being justified mainly by crime statistics, response times and arrest numbers, as it has been a common practice since the beginning of the $20^{\text {th }}$ century (Cooper, 2014). The arguments sketched above provide reasons why the police or other law enforcement institutions need also other ways of maintaining legitimacy than justification by effective fulfilment of their main task.

In the community policing model, there is also certain risk of raising an impossible mandate. It could happen due to widening the perceived scope of police tasks from "crime control" to "social wellbeing". For instance Meares (2012) claimes for rightful policing, as a model overcoming drawbacks of the crime control model and of policing based purely on laws. Her model is based on connection of the police with the community that can be built through respecting people's rights - principles of fair and respectful treatment. This partially overlaps with aspects of effectiveness and lawfulness, but goes beyond it. For Meares, the police should not only represent a lawful tool for fighting crime, but also become an active social actor and a creator of common social identity, thus promoting a democratic environment. There is however disagreement on whether the scope of the police should be enlarged to include also the extra-roles which is suggested in the community policing model, especially in the specifications close to view of Meares (see for instance Herbert, 2006). Huq, Jackson and Trinkner (2016) note that in the current state of widening police tasks beyond "crime control" in a narrow sense, there is a higher probability that people would consider the police activities as unjustified because of too much intervention in their private lives.

Moreover, the demands that the police are facing and their official tasks are becoming rather differentiated. If we perceive legitimacy as an overlap between role and its 
fulfilment, we can expect harder achievement of legitimacy in such conditions. There are numerous ways how the social role of the police can be constructed and probably the more differentiated social systems are, the more diverse are also the expectations from the police, or criteria of their legitimacy. One reason why legitimacy of criminal justice has become a top issue in current criminology may be the rising social and value plurality. Is it fair that the police stop and search primarily non-white civilians? Is it desirable that the police struggle for "clean streets" (without homeless people)? Different social groups will probably stress different issues or aspects that the police should take care of. Vaughan (2007, p. 347) articulates the concerns of policing in age of pluralism, where [p] olice forces may be subject to a range of different claims, emanating from central government, business groups, local communities, newsmedia and campaigning bodies. In the conditions of questioning policing objectives, he finds the solution for reconciling different voices in upholding the equality of status of all [...], guided by the principle of avoiding domination by tracking the interests of all those who are affected by policing decisions (ibid: 363 ). This perspective is embedded in the current criminological focus on legitimizing power of procedural fairness (see chapter Procedurally fair policing).

Herbert (2006) assumes that also the main ways in which the modern police try to earn their legitimacy are conflicting with each other. Instead of strength, the manifested police "subservience" to people (emphasized in community policing) has become the new legitimization criterion. But the social criteria for legitimacy in current Western society are still multiple (neutrality, responsiveness, power, professionalism) and somewhat clashing. The police can still earn credibility and legitimacy through manifesting high social status (for instance through presenting themselves as distinct powerful experts) among some people. Professional work can bring the police prestige, although professionalism goes against appeals to responsiveness (legitimization through distance versus closeness to people). The desired focus of the police on neutrality may also turn out to be rather distancing it from the public - it stresses the law, not the citizen's satisfaction as the criterion of good work. Moreover, the police in their view may still want rather "blind obedience" for being effective and protected and thus may strive for coercive power, irrespective of the current trend of community policing (ibid.). This may be especially true in transitory democracies. For instance, older Slovenian police officers and male police officers were likely to defend sever punishment for offenders compared to younger officers and police women. The findings are interpreted as an evidence of persistence of authoritarian police orientation in postmodern society (Kury et al., 2009). Likewise, according to Croatian policemen, community policing is largely not accepted among lower levels of the police staff (Kutnjak Ivković, 2009).

A somewhat pragmatic solution to problems of policing in plurality can be found in the work of organizational theorists. In the era of social plurality, the connecting power of overarching symbols and values that are held across different social groups can be limited. To win a wide social support it can be necessary to create a dense net of meanings to which people from various social groups can relate (Suchman, 1995). This is in reality reached for instance by maintaining multiple police identity as a part of the impression management (Sillince \& Brown, 2009) - an organization's identity serves as a symbol inducing integrity and meaningfulness and as such can be of use in maintaining organizational 
legitimacy (ibid.). ${ }^{6}$ Sillince and Brown analyzed an online communication of the British police, where they identified different discursive formulations which they understand as appeals to multiple identities. They assume that inconsistent discourses are used by the police as effective strategy for satisfying different social groups or inconsistent expectations. Using discourse analysis, the authors recognized three broad categories of police claims - about their effectiveness, progress and relation to community - as well as functions of each group of the claims. Claims about effectiveness may raise police pragmatic legitimacy, while claims about ineffectiveness can be resulting in fear of crime and granting the necessity of the police and need of public assistance. Claims about relation to community can be understood as empathizing with the public and lead to better identification with the police, while claims about distance from community may serve to present the police as specialists who know what they are doing and thus grant them pragmatic legitimacy. Claims about progress can represent commitment to social norm of improvement, while claims about no progress can lead to a perception of honest police seeking for an improvement. The police make use of the multiple discourses/different communication strategies depending on the situation or audience. Denef, Bayerl and Kaptein (2013) empirically identified two types of British police communication strategies on Twitter - an instrumental one (the police as distant crime-control power) and an expressive one (the police connecting closely with the public). Both strategies are observed to be functional, though the authors assume that the situational suitability of the communication strategy is vital for maintaining police legitimacy. In this way, the aspects of the crime control model and the community model can be seen as complementary. Nevertheless, the risk of loosing police legitimacy in terms of integrity by pragmatic choice of rhetoric is not ruled out.

\section{Legitimacy and normative model of compliance}

The current criminological conceptions of police legitimacy (Bottoms \& Tankebe, 2012; Huq, Jackson, \& Trinkner, 2016; Tyler \& Huo, 2002) draw heavily on the definition by social psychologist Tyler (2006b) and political theorist Beetham (1991). Tyler (2006b, p. 375) described legitimacy as a psychological property of an authority, institution, or social arrangement that leads those connected to it to believe that it is appropriate, proper, and just. Because of legitimacy, people feel that they ought to defer to decisions and rules, following them voluntarily out of obligation rather than out of fear of punishment or anticipation of reward. Beetham (1991) understands (political) legitimacy in democracy as a multidimensional construct. He described three criteria of legitimacy ("the rules of power") - 1) legality or acting according to laws, which rests on 2) shared values, while there is an evidence of 3) consent or felt obligation to obey on the side of the subordinate.

Each of these aspects is qualitatively different for Beetham (1991) and also has different sources. He criticized legitimacy conception of Weber, who equaled legitimacy with a belief of the governed, when he highlighted the obligating core of legitimacy: Together, these criteria provide ground not for a belief in legitimacy', but for those subject to power to

6 The relationship between identity and legitimacy is bidirectional. It has been also shown that once a rule or group is legitimized, people identify with it more (Tyler, 2006b). 
support and cooperate with its holders; grounds, that is to say, not for belief, but for obligation (Beetham, 1991, p. 13). Beetham was aware that legitimacy demands both normative and instrumental grounding - both a morally authoritative source for government, and an ability to satisfy the ends which justify its enormous concentration of power (Beetham, 1991, p. 137). However, he refused pure rational choice theory of human behaviour. Likewise, institutionalist theories offer models connecting instrumentally and morally driven modes of action. Crank (2003) adapted Giddens' theory of social action (1984) to model action of police organizations as well as individuals in relation to them. He claims that conscious course of action may be intentional and rationally instrumental, but the instrumentality is limited because it cannot be set free from normative factors such as cultural beliefs or language meanings (similarly like individual action cannot be separated from its social background in the Gidden's theory of structuration).

\section{Two facets of police legitimacy}

Not surprisingly, the researchers of police legitimacy in criminology are also criticizing the crime-control model as insufficient because of its grounding in rational choice theory. They offer an empirical verification of a normative model of behaviour related to criminal justice institutions (compliance with the law/cooperation with the criminal justice) (Jackson et al., 2016a). Compliance with the police and the law is shown to have largely normative causes, stemming from normatively conceived police legitimacy more than from fear of being caught or effectiveness of the police (altough for people or cultures holding authoritarian values, effectiveness may be more important - Jackson et al., 2016b).

The prevailing model (Jackson et al., 2016a) depicts legitimacy as consisting of 1) normative consent (a sense that one should obey the legal organization out of moral or legal duty, that it is entitled to be obeyed ${ }^{7}$ and 2) appropriateness (belief that the organization has the right to power which can be based upon normative alignment - a sense of shared conception of right and wrong with the authority). ${ }^{8}$ Jackson et al. (2016a) propose equal standing of both parts, yet separate. In European and American society, consent and appropriateness have been found to yield a distinct impact on compliance and cooperation (Jackson \& Gau, 2015). The researchers thus expect that these two aspects of legitimacy are evaluated in people's minds independently and may motivate different behaviour (ibid.). ${ }^{9}$

The percevied right to power (appropriateness) is fueled by perceived lawfulness (or legality) and morality (or bounded authority) of the police, which includes perceptions of police corruption or integrity. The team originally stated that bounded authority is distinct, we note from the concept of legality, which others have posited as important albeit without evidence. The effect we find is from socially derived conceptions of appropriate

7 The idea of a free consent dates back to Roussuau and Locke who saw it as a root of social agreement between the state and the governed enabling formation of organized society.

8 Compared to trust in the police, the belief in normative alignment is more concerned with reflection of one's own community moral values, than with performing according to norms specifying appropriate power possession (Jackson \& Gau, 2015). Currently, it is equated with the perceived right to power (Huq, Jackson, \& Trinkner, 2016) or with the identification with the police (Tyler \& Fagan, 2008).

9 In the UK data sample, appropriateness seems to be relatively stronger predictor of police legitimacy and willingness to cooperate with the police than felt obligation to obey (Jackson et al., 2016b). 
behaviour, rather than legally defined parameters of police authority (Huq, Jackson, \& Trinkner, 2016, p. 14). However, in the most recent study (Jackson et al., 2016b), they provide empirical proof for combining the (in UK data sample) highly correlated perceived police lawfulness and police morality into one dimension of police empirical legitimacy (with the other dimension remaining the normative consent or perceived obligation to obey). However, in other social contexts there may be a greater distinction between lawfulness and morality.

The two facets of police legitimacy (appropriateness and consent) are generally accepted in criminology research, but the theories differ in the hypothesized structure of the relations. For instance in some theories they form a single indicator of legitimacy, in other theories they are comprehended as two distinct indicators, possibly causally related. There is also certain disagreement on how to conceptualize other related aspects of police legitimacy. Tankebe and colleagues (Bottoms \& Tankebe, 2012; Tankebe, Reisig \& Wang, 2016) view procedural fairness, distributive fairness, effectiveness and legality (lawfulness) as components of legitimacy, for Jackson an colleagues those are rather legitimizing factors of trustworthiness (Huq, Jackson, \& Trinkner, 2016; Tyler 2006b), while legitimacy ${ }^{10}$ would be their outcome.

Recently, Huq, Jackson and Trinkner (2016) made use of the dual conception of legitimacy consisting of normative alignment and duty to obey. They try to develop a universal model of police legitimizing practices without the necessity to specify any universal values or practices leading to legitimacy in all social contexts. In other words, it is possible, that the reasons for perceived normative alignment and consent to obey would vary depending on police roles and culture in general.

\section{Relation between trust and legitimacy}

The above sketched conception of police legitimacy may seem very close to common understanding of trust in the police. Frequently, trust is understood as an important police resource for compliance and cooperation with the police. Is it worth distinguishing trust from legitimacy?

Social scientists try to find a fine line between organizational legitimacy and trust in it, especially if they see both concepts as empirically based on what is seen as valuable in the society. ${ }^{11}$ Tyler (2006b) understood trust and legitimacy of the police as very close concepts, even though legitimacy for him is stronger than trust, because it functions as a reservoir of support (loyalty) even when the organization's action is not approved. Jackson, Huq and Trinkner (2016) and others (Lyons, 2002) see it also connected, when understanding trustworthiness as predictor of perceived legitimacy. However, other scholars (Bottoms \& Tankebe, 2012; Kaina, 2008) warn not to merge trust (as a sense that institutions are performing according to prevalent norms) and legitimacy (as a conviction that

10 As a contentless source of normative alignment or an overarching belief that legal authorities act according to societal expectations of rightful conduct in their use of authority (Huq, Jackson, \& Trinkner, 2016, p. 16 ; p. 3 ).

11 This is in contrast to politics, where it is only trust that bears the moral dimension (integrity, common good), while legitimacy is seen as procedural - see for instance account of political legitimacy in Rosanvallon (2008). 
institutions are acting in accordance to one's own moral principles). Others (Johnson, Maguire, \& Kuhns, 2014) show the empirical distinction between trust and legitimacy of the police. There are situations when people see their institution as legitimate, yet do not trust it (ibid.). Peršak (2014) describes legitimacy as a safety tool against bad practices of trusted institutions - for it is a more objective property than trustworthiness. The objectivity is granted due to social nature of legitimacy beliefs. Recently, Jackson and Gau (2015) attempted to delineate institutional trust and legitimacy more precisely, when they related trust to positive individual expectations about valued behaviour ${ }^{12}$ from individual representatives of the institution (policemen), ${ }^{13}$ while legitimacy is a social belief based on appropriateness of power of the police as an institution. In the context of the police, trust and legitimacy can be seen as distinct, yet related and interdependent, because individual policemen also possesses power of the institution (ibid.). Thus they define institutional trust as a belief that the police use their power lawfully and appropriately and as such it reflects the belief in the right of the police to possess power (aspect of legitimacy) according to them. An argument for conceptual distinction is brought by numerous studies where people judge trustworthiness and legitimacy of the police relatively independently.

With regard to the above mentioned approaches, we can comprehend the relation between trust and legitimacy similarly as the relation between the individual and the social, they are mutually interconnected, but cannot be merged. Their joint usefulness resides in development of social theories based on individual data.

\section{Limits to the normative model}

The seemingly robust finding that perceived appropriateness of the police and felt duty to obey the police lead to compliance with the law and cooperation with the police should not be taken for granted. There may naturally be some confounds in the identified relationship between legitimacy and compliance/cooperation - factors that would influence both perceived legitimacy and compliance/cooperation which could mean there is virtually no real relationship between them. This situation can be controlled by using complex structural models when analyzing the data, which is true only provided that the scholars are aware of the potential confounds and can measure them. For instance, Reisig, Wolfe and Holtfreter (2011) found out that legitimacy (and reversely legal cynicism) are connected to compliance/offending even when statistically controlling for self-control as a potentially confounding variable. There certainly are intervening factors in the postulated relationship between legitimacy and cooperation, such as whether the person has been recently victimized or the type of crime committed. For instance in the study of Tankebe (2013) it turned out, that cooperation was predicted by different factors among recent victims of crime than the others. For the victims, no effect of distributive fairness and weak effect of legality was found while perceived police effectiveness had a significant positive effect. In the non-victim population legality was significantly shaping cooperation, distributive fairness had a weak significant effect and perceived police effectiveness had a negative effect on cooperation. The felt obligation was found to influence willingness

12 Fulfilling the core function of the institution.

13 Or police behaviour in general (confidence). 
to cooperate among young Slovenians in case of break-ins and lost wallets, but not in the bribery of the official authorities (Reisig, Tankebe, \& Meško, 2012). Another limit is methodological - most of the studies are cross-sectional, even if trying to prove a causal relationship between legitimacy and compliance/cooperation. Apart from that, the results, however persuasive, have a limited value, because they are based on people's beliefs about the police rather than their real experiences with the police.

Moreover, as Tankebe (2013) states there may be other more powerful factors determining legitimacy, compliance and cooperation that have often not been considered in similar studies - habits, fear etc. (an exception is for instance the study by Jackson et al. 2016a). Jackson at al. (2016a) admit, there can be other than normative reasons for perceived legitimacy of the police. Their normative theory of legitimacy originally reflected the Weber's (1964) understanding of authority ${ }^{14}$ as a result of a social belief (Huq, Jackson, \& Trinkner, 2016). But as the system justification theory suggests, people may grant legitimacy to systems that do not align with their values, because of psychological needs for stability and security (Jost, Banaji \& Nosek, 2004). As Garland (2001) puts it - we are used to the existence of criminal justice institutions so they seem to be eternal. Maintaining the status quo can be more precious than having the police we want. This may also be the reason why people may choose passive tolerance of the police they disapprove over active protests against it (see also Hirschman's exit and escape theory above). This could serve as an invitation for development of competing models and new perspectives in police legitimacy research. Besides that, there are surely aspects of police legitimacy that are not covered by the main course of theorizing of Jackson and his colleagues. Despite calls for plural conceptions of legitimacy in criminology (Huq, Jackson, \& Trinkner, 2016), the literature on legitimacy of criminal justice institutions has been almost exclusively devoted to procedural aspects (see further) and the police or prisons (Peršak, 2014). Even though the literature on legitimacy of European law is quite rich, especially in regard to European Union, it is mainly focused on legal perspective. What is also missing, is a macro theory of police legitimacy that would deal with structural factors.

\section{Sources of police legitimacy}

In this section, we discuss two complementary sources of police legitimacy: police performance in a wide sense and a broader social normative context impact of which is channeled through legal socialization. These two groups of factors should be understood as an illustration of the micro and macro aspect of police legitimacy, altough they are certainly not the sole sources of it.

\section{Police performance}

Eck and Rosenbaum (1994) enumerate three basic criteria of police performance: effectiveness, efficiency and equity (or fairness). Police performance in such a wide sense

14 Action, especially social action which involves social relationships, may be oriented by the actors to a belief (Vorstellung) in the existence of a 'legitimate order' (Weber, 1964, p. 124). 
has probably its normative and instrumental dimensions that are empirically distinct people assess them relatively separately. A recent empirical research in England and Wales by Huq, Jackson and Trinkner (2016) identified three independent components of policing as vital for legitimacy of the police: procedural fairness, effectiveness and bounded authority (that the police limit or do not misuse their power ${ }^{15}$ ), while distributive fairness, electronic surveillance (intrusive investigative techniques) and lawfulness turned out not to be significant in predicting legitimacy of the police.

It is assumed that the above mentioned policing factors do not influence citizen's behaviour through impacting legitimacy to the same extent and under the same conditions. For instance the impact of instrumentally understood police effectiveness (crime control through coercion power) on compliance with the law was found to be rather small compared to impact of procedural fairness in New York City (Tyler \& Fagan, 2008). Moreover instrumental police effectiveness is functional largely in reducing just instrumental types of crime (burglary or thefts) and when only surveillance is expected. It makes instrumental strategies to control crime quite ineffective and costly (ibid.). That is why the attention of criminologists and policy makers turned to normative components of police performance as a potential source of police legitimacy. In the next section we show how police legitimacy can be bolstered by procedural fairness.

\section{Procedurally fair policing}

Fair procedures consist of being neutral (objective decision making and providing equal treatment to citizens), giving voice (allowing citizens an opportunity to tell their side of the story and have an input into the issue at hand), being respectful (treating citizens with dignity and acting respectfully), and being accountable (providing citizens with reasoned explanations for decisions made) (Jackson et al., 2016a, p. 6). In criminology research it was found that empirical legitimacy of the police and other legal institutions can be strengthened through perceptions of procedurally fair policing, independently from the impact of perceived police effectiveness (Tyler \& Fagan, 2008). Manifesting values such as fairness on the side of the police may make people trust the police more and influence their law related behaviour in the long-term. Not only do fair police make people more satisfied with it and compliant with the rules of the society (laws) (Tyler, 2006a), ${ }^{16}$ they lead them also to greater cooperation on the tasks of the state authorities (Blader \& Tyler, 2009; Bradford, 2014; Tankebe, 2013). It seems that procedural fairness can function also as a buffer against negative impacts of other police actions such as involuntary contact with it (stop and search) (Huq, Jackson, \& Trinkner, 2016) which can negatively influence one's trust in it and lower their perceived legitimacy (Skogan, 2006; Tyler, Fagan, \& Geller, 2014).

The explanation of why the fair procedures matter is twofold: First, it is seen in relevance of perceived fariness to positive social identity. When the state authorities treat people fairly, they find it as a sign of being valued within the society and that enhances

\footnotetext{
15 ... that police do not abuse the authority that has been vested in them, but rather comply with shared norms of the appropriate official conduct. ... The effect we find is from socially derived conceptions of appropriate behaviour, rather than legally defined parameters of police authority (ibid.: 14).

16 Similarly once something is seen as legitimate, it is more likely to be seen as fair (Tyler, 2006b).
} 
their sense of social identity (Jackson et al., 2016a). The theory expects that there would be only few people not valuing their social status within the social groups that the police represent. However, it is not fully clear, how minority members who do not identify themselves with the nation, state or community (or counter identify with it) would react. ${ }^{17}$ Second, perceived police fairness is a sign of police morality in the eyes of the policed and morally acting institutions have higher chance to be granted legitimacy (Jackson et al., 2016b). Governmental institutions such as the police cannot gain legitimacy only through effective production of outcomes in the same way as business or technical organizations, if they are seen as responsible for promoting values of their institutional environment including their electorate (Crank, 2003).

In the theory of isomorphism, it has been suggested that legitimacy can be gained by adapting to existing standards, norms or structures (Suchman, 1995, see also Bourdieu, 1986). Institutions can profit from adjusting to structures and forms of already legitimized institutions in the field (which is in organizational literature known under the term isomorphism - Meyer \& Rowan, 1977) or even from integration with institutions out of the field (Suchman, 1995). Part of the legitimacy of the police can be for instance granted through their connection to legitimate state and its laws (however, the police often earns greater public trust than political institutions). Isomorphism can be also found in adapting to prevailing ideals of legal rationality ${ }^{18}$ and professionalization (ibid.). That is why we expect that adjusting to democratic norms such as procedural fairness should lead to greater perceived legitimacy of the police, at least within democratic societies. Indeed, across developed European and American democratic societies the models of police legitimacy correspond to the identified importance of police procedural fairness (Homolová, 2014; Jonathan-Zamir \& Weisburd, 2013; Moravcová, 2016; Reisig, Tankebe, \& Meško, 2012).

The empirical results thus overall provide an argument for enhancing police legitimacy through training police officers' skills and will to act in procedurally fair ways (Mastrofski et al., 2016). There are multiple functional ways how to promote perceived procedural fairness or compliance with the police. Mazerolle et al. (2013) conducted a meta-analysis of 30 American evaluative studies on interventions ${ }^{19}$ aimed at strengthening procedural fairness of the police or their legitimacy. Irrespective of the type of intervention, an overall positive effect of the interventions was observed on perceived procedural fairness of the police, citizen cooperation, compliance and satisfaction with the police or confidence in the police. ${ }^{20}$ The authors deduce, that the actual vehicle (or intervention mode) for police to engage with citizens is less important for fostering positive outcomes than the substantive content of the interaction itself (ibid.: 76).

17 An interesting finding by Huq, Tyler and Schulhofer (2011) indicates, that procedural fairness leads to willingness to cooperate with the police even among British Muslims, who probably do not have a strong tie with the police due to low identification with British state. Nevertheless, fair police treatment did not change their views of police legitimacy.

18 For effects of rationality on legitimization see also Tyler (2006b).

19 Training, directive or organizational innovations, for instance routine patrols, traffic stops, community policing, reassurance policing, problem-oriented policing, conferencing.

20 However, the effect on perceived police legitimacy itself was not significant (probably due to limited amount of examined studies). 
However, the knowledge of principles of fair treatment and skills alone do not guarantee that policemen will behave fairly and respectfully in reality. As Mastrofski and colleagues (2016) have revealed in their observational study in two American police departments, procedurally fair approach was more probable for instance when the policemen subjectivelly considered people as victims or helpless. The authors interpret their findings with respect to social roles and social scenarios - according to them the practice of procedural fairness can be enhanced or impeded through social schemes, especially when formal rules delineating delivering of fair procedures are limited.

\section{Legal socialization}

Policing is not the only source of gaining police legitimacy. There are without doubt other strong factors of it, such as social values. To paraphrase Ponsaers (2016), police legitimacy is not a property of the police itself. In this section, we provide an account on the impact of socially held general views of the police and their impact on perceived police legitimacy.

The empirical evidence of the power of cultural constructs in policing evaluation has been offered in studies on legal socialization. In the process of legal socialization, people socially learn legal values (stable ideals of how legal institutions and people should behave) and more volatile opinions about legal institutions and the law (Trinkner \& Tyler, 2016). Basically, there are two types of attitudes towards legal authorities, corresponding to consensual and coercive models of policing. The former is based on normative grounds, the latter on dominance (ibid.). As an example of a normative type of a social belief we could rank also the above mentioned ideas of community policing (some would call it even a myth - depicting the community as an idealized small social network on the basis of traditional neighbourhood, and the police officers as its careful guardians Crank, 2003).

Legal socialization occurs through learning socially valued beliefs and behaviours in legal as well as non-legal contexts (where authority plays a role). The beliefs can be transmitted through a direct contact with the police, massmedia discourse and images as well as behaviour and opinions of our significant others. Research shows that our perception of police legitimacy can be influenced by opinions and behaviour of our community or peers (Fagan \& Tyler, 2005; Nix et al. 2015), as well as authority figures in the childhood such as parents and teachers (Trinkner \& Cohn, 2014). ${ }^{21}$ For instance, when parents treat their child with respect, it may be later reflected in their positive and cooperative relation to other authorities, including the legal ones (Trinkner \& Tyler, 2016). In contrast, coercive parenting with use of physical punishments, or inconsistent rules enforcement, may lead to alienated relations with authorities and antisocial attitudes (ibid.). A transfer of parental attitudes to legal authorities has been documented in a longitudinal study using data from the Pathways to Desistance survey ${ }^{22}$ (Wolfe, McLean, \& Pratt, 2017). The authors found out that parental legitimacy attitudes towards the police are connected to

21 Apart from those social factors, personality may also play role in forming attitudes about legitimacy of the police in socialization (lower level of self-control is associated with lower perceived legitimacy Wolfe, 2011).

22 The sample consisted of delinquents aged 14-17 and their parents (ibid.). 
attitudes of their children irrespective of the children's later experience with the police. For instance, an unfair police related encounter experienced by the parents can be translated into their belief and influence the next generations through socialization (ibid.). Similar results were presented by Cavanagh and Cauffman (2015) concerning similarity of attitudes among delinquent sons and their mothers. These results advert to at least partial family socialization of legitimacy attitudes.

Legal socialization may intervene also in the above mentioned structure of relations between police procedural fairness and police legitimacy. Although there is a preliminary evidence that trustworthiness and fairness of legal authorities are shaping the perceived police right to be obeyed even in African states (Levi, Sacks, \& Tyler, 2009), there are certainly cultural differences in the model of relations. For instance, in South Africa and Ghana, procedural fairness seems not to be of the same importance in shaping police legitimacy as it has been found in the US, UK or Australia (Bradford at al., 2014; Tankebe, 2009). For South Africans, not only fair procedures, but also effectiveness mattered in shaping duty to obey and moral alignment (the two legitimacy aspects). Perceived fairness and effectiveness were predicted not only by satisfaction with contact with the police, but also by fear of crime (Bradford et al., 2014). Apart from that, trust in government was important when judging police legitimacy. This may be explained by variability in socially ascribed police (or any authority) tasks and roles. As Brockner et al. (2001) found, giving voice as an aspect of procedural fairness was relatively more important for judgments about legitimacy (in managerial context) among people from low-power distance countries (Germany, the US) compared to people from high-power distance countries (China, Mexico, Hong Kong). That is probably due to different normative expectations among the cultures about how much voice people should be given (ibid.). In this way, people from Ghana or South Africa may be socially impacted to appreciate fairness relatively less. Also more general social values or beliefs may be at play when evaluating the police, for instance xenophobia (e.g. people want the police to be unfair to minorities), or rather on the contrary norm of equality and representativeness (e. $g$. the police are demanded to represent the whole society including the minorities) (see for instance Kešetović, 2009).

Nevertheless, the cultural variability in the proposed scheme of the relationship between legitimacy and support for institutions might result also from other factors than values, social norms or roles. It may be caused by different levels of salience of legitimacy issues in different socio-cultural contexts. It is presumed that the more salient legitimacy issues are, the more cognitively accessible and also more differentiated attitudes on legitimacy issues arise. That can change not only the size of the effects but even the structure of relations among different attitudes (Johnson, Maguire, \& Kuhns, 2014). Also a legitimizing effect of the state should not be omitted - a corrupted government can hardly grant high status or legitimacy to their police.

Overall it is assumed that where crime, institutional corruption or social inequality are more present, utilitarian factors such as police effectiveness will be relatively more important for people when deciding whether to trust and help their police.

Herbert (2006) notes, that stressing procedural fairness may not earn legitimacy even in Western developed countries with relatively low crime levels due to colliding cultural myths concerning policing. He asserts, with some empirical evidence, that appeals to 
police superiority are still present in our society. There are people who expect more robust solutions from the police, some police officers themselves may construe themselves as separate from the public and thus not internalize the community policing model. Herbert consequently suggests introducing formal ways of citizen oversight of the police and focusing police training on problematizing culturally transmitted images of policemen as authoritarians, strong protectors of the weak and powerful moral arbiters. He also suggests that extending the police role beyond pure crime control (implicit in community policing model to him) may actually paradoxically reinforce the cultural myth of powerful and superior police. Thus, albeit the findings about legal socialization may be read as an argument for culturally sensitive policing in the quest for police legitimacy, there is also an inherent risk that personalizing the police approach may legitimate it in unintended ways.

\section{Discussion}

The review of literature on sources and consequences of police legitimacy in current social contexts emphasized importance of legitimacy for active and passive support of the police as well as several problems in theoretical and methodological conceptualization of it. The prevailing criminological model of police empirical legitimacy consisting of two interdependent normative aspects (normative consent and sense of appropriateness) was introduced. A support for such operationalization was sought also in institutionalist theories that contrast the institutional environment to the technical one in terms of their legitimization sources.

Empirical evidence that police legitimacy is shaped by different aspects of police performance and specifically by their procedural fairness was presented. An additional explanation for the identified impact of police fairness on perceived legitimacy (usually explained by psychological phenomena) stemming from organizational theory of isomorphism was offered. At the same time, important limitations to the universal applicability of procedural fairness model such as legal socialization or effects of social roles and scenarios were introduced. That leads us to demand greater attention of criminologists to cognitive types of police legitimacy that are usually overlooked in the mainstream criminology. Questions such as how the police construct and sustain their positive image and how legitimization myths (including not only crime-control but also community policing model) or social schemes influence policemen work need in our view further elaboration.

Proceeding from our review, the anticipated pathways of police legitimacy research are largely psychological. We can expect development of micro-level theories in the field of legal socialization as well as testing the salience hypothesis in regard to legitimacy attitudes, or incorporating the theory of system justification in the model of compliance with the law. This approach may lead to greater consideration of emotional sources of police legitimacy at the individual level (and perhaps blurring the division between normative and instrumental empirical legitimacy).

The demand for micro level approaches is natural given by their relatively easy testability and applicability in criminal policy. However, a profound understanding of human legal behaviour demands enlarging the scope to macro-level phenomena. Most people 
do not create their opinion toward the police primarily through direct experiences with it because their encounters with the police are limited. People are part of larger social structures that socialize them into specific sets of expectations about criminal justice. Criminology should pay attention to social factors of police legitimization in the search for feasible ways of plurality policing. The two outlined research tracks can also mutually inspire each other - for instance we could explore effects of democratization, legal socialization and salience of police legitimacy and criminality issues on police legitimacy - in stabilized democracies we can expect more attention to institutional legitimacy and at the same time weaker salience of crime related issues. How do these factors impact formation of attitudes towards the police and legitimization criteria in the democratization process?

The endeavour to understand better the mechanics of police legitimacy yields also certain risks. Above all, researchers should be aware of ethical issues related to legitimacy and treat legitimacy as a neutral term (see Hough et al., 2016). Police training should naturally highlight these risks accordingly, should the democratic police succeed in promoting social well-being.

\section{REFERENCES}

Beetham, D. (1991). The legitimation of power. London: Macmillan Education.

Blader, S. L., \& Tyler, T. R. (2009). Testing and extending the group engagement model: linkages between social identity, procedural justice, economic outcomes, and extrarole behavior. Journal of Applied Psychology, 94(2), 445-464.

Bottoms, A., \& Tankebe, J. (2012). Beyond procedural justice: A dialogic approach to legitimacy in criminal justice. The Journal of Criminal Law and Criminology, 102(1), 119-170.

Bourdieu, P. (1979). Symbolic power. Critique of Anthropology, 4(13-14), 77-85.

Bourdieu, P. (1986). The force of law: Toward a sociology of the juridical field. The Hastings Law Journal, 38, 805-853.

Bradford, B. (2014). Policing and social identity: Procedural justice, inclusion and cooperation between police and public. Policing and Society, 24(1), 22-43.

Bradford, B., Huq, A., Jackson, J., \& Roberts, B. (2014). What price fairness when security is at stake? Police legitimacy in South Africa. Regulation \& Governance, 8(2), 246-268.

Bradford, B., \& Loader, I. (2016). Police, crime and order: The case of stop and search. In B. Bradford, I. Loader, B. Jauregui \& J. Steinberg (Eds.), The SAGE Handbook of Global Policing (241-260). London: SAGE Publications.

Brockner, J., Ackerman, G., Greenberg, J., Gelfand, M. J., Francesco, A. M., Chen, Z. X., \& Shapiro, D. (2001). Culture and procedural justice: The influence of power distance on reactions to voice. Journal of Experimental Social Psychology, 37(4), 300-315.

Cavanagh, C., \& Cauffman, E. (2015). Viewing law and order: Mothers' and sons' justice system legitimacy attitudes and juvenile recidivism. Psychology, Public Policy, and Law, 21(4), 432-441.

Clark, I. (2005). Legitimacy in international society. Oxford University Press.

Coicaud, J. M., \& Curtis, D. A. (2002). Legitimacy and politics: A contribution to the study of political right and political responsibility. Cambridge University Press.

Cooper, J. A. (2014). In search of police legitimacy: Territoriality, isomorphism, and changes in policing practices. El Paso: LFB Scholarly Publishing.

Crank, J. P. (2003). Institutional theory of police: A review of the state of the art. Policing: An International Journal of Police Strategies \& Management, 26(2), 186-207.

Denef, S., Bayerl, P. S., \& Kaptein, N. A. (2013). Social media and the police: Tweeting practices of British police forces during the August 2011 riots. In J. A. Konstan, E. Chi \& K. Höök (Eds.), Proceedings of the SIGCHI conference on human factors in computing systems (3471-3480). New York: ACM Press. 
Eck, J. E., \& Rosenbaum, D. (1994). The new police order. Effectiveness, equity, and efficiency in community policing. In D. Rosenbaum (Ed.), The challenge of community policing: Testing the promises (3-23). Thousand Oaks: SAGE Publications.

Fagan, J., \& Tyler, T. R. (2005). Legal socialization of children and adolescents. Social Justice Research, 18(3), 217-241.

Garland, D. (2001). The culture of control. Oxford University Press.

Giddens, A. (1984). The constitution of society: Outline of the theory of structuration. Berkeley: University of California Press.

Herbert, S. (2006). Tangled up in blue: Conflicting paths to police legitimacy. Theoretical Criminology, 10(4), 481-504.

Hirschman, A. O. (1970). Exit, voice, and loyalty: Responses to decline in firms, organizations, and states. Harvard University Press.

Homolová, P. (2014). Trust in criminal justice and compliance with the law in Czech society: Testing the Normative Hypothesis on 1999 and 2011 Samples. Varstvoslovje, 16(4), 412-434.

Hough, M., Bradford, B., Jackson, J., \& Quinton, P. (2016). Does legitimacy necessarily tame power? Some ethical issues in translating procedural justice principles into justice policy. (Law, Society and Economy Working Papers 13/2016). London School of Economics and Political Science.

Huq, A. Z., Tyler, T. R., \& Schulhofer, S. J. (2011). Mechanisms for eliciting cooperation in counterterrorism policing: Evidence from the United Kingdom. Journal of Empirical Legal Studies, 8(4), 728-761.

Huq, A. Z., Jackson, J., \& Trinkner, R. (2016). Acts that legitimate: Widening the array of predicate policing practices. (Public Law and Legal Theory Working Paper No. 570). University of Chicago.

Jackson, J., Huq, A. Z., Bradford, B., \& Tyler, T. R. (2013). Monopolizing force? Police legitimacy and public attitudes toward the acceptability of violence. Psychology, Public Policy, and Law, 19(4), 479-510.

Jackson, J., \& Gau, J. M. (2015). Carving up concepts? Differentiating between trust and legitimacy in public attitudes towards legal authority. In E. Shockley, T. M. Neal, L. M. PytlikZillig \& B. H. Bornstein (Eds.), Interdisciplinary perspectives on trust: Towards theoretical and methodological integration (49-69). Springer International Publishing.

Jackson, J., Bradford, B., MacQueen, S., \& Hough, M. (2016a, September 3). Truly free consent? Clarifying the nature of police legitimacy. Retrieved from http://dx.doi.org/10.2139/ssrn.2620274.

Jackson, J., Hough, M., Bradford, B., \& Kuha, J. (2016b). Empirical legitimacy as two connected psychological states. In G. Meško \& J. Tankebe (Eds.), Trust and legitimacy in criminal justice (137-160). Springer International Publishing.

Jauregui, B. (2013). Beatings, beacons, and big men: Police disempowerment and delegitimation in India. Law \& Social Inquiry, 38(3), 643-669.

Johnson, D., Maguire, E. R., \& Kuhns, J. B. (2014). Public perceptions of the legitimacy of the law and legal authorities: Evidence from the Caribbean. Law \& Society Review, 48(4), 947-978.

Jonathan-Zamir, T., \& Weisburd, D. (2013). The effects of security threats on antecedents of police legitimacy: Findings from a quasi-experiment in Israel. Journal of Research in Crime and Delinquen$c y, 50(1), 3-32$.

Jost, J. T., Banaji, M. R., \& Nosek, B. A. (2004). A decade of system justification theory: Accumulated evidence of conscious and unconscious bolstering of the status quo. Political Psychology, 25(6), 881-919.

Kaina, V. (2008). Legitimacy, trust and procedural fairness: Remarks on Marcia Grimes' study. European Journal of Political Research, 47(4), 510-521.

Kane, R. J. (2003). Social control in the metropolis: A community-level examination of the minority group-threat hypothesis. Justice Quarterly, 20(2), 265-295.

Kešetović, Ž. (2009). Understanding diversity in policing: Serbian perspectives. Policing: An International Journal of Police Strategies \& Management, 32(3), 431-445.

Kury, H., Meško, G., Mitar, M., \& Fields, C. (2009). Slovenian police officers'attitudes towards contemporary security threats and punishment. Policing: An International Journal of Police Strategies \& Management, 32(3), 415-430.

Kutnjak Ivković, S. (2009). The Croatian police, police integrity, and transition toward democratic policing. Policing: An International Journal of Police Strategies \& Management, 32(3), 459-488. 
Kutnjak Ivković, S. K., Haberfeld, M., Kang, W., Peacock, R., \& Sauerman, A. (2016). A multi-country comparative study of the perceived police disciplinary environments. Policing: An International Journal of Police Strategies \& Management, 39(2), 338-353.

Levi, M., Sacks, A., \& Tyler, T. (2009). Conceptualizing legitimacy, measuring legitimating beliefs. American Behavioral Scientist, 53(3), 354-375.

Lipset, S. M. (1983). Political man: The social bases of politics. London: Heinemann.

Loader, I., \& Mulcahy, A. (2003). Policing and the condition of England: Memory, politics and culture. Oxford University Press.

Lyons, W. (2002). Partnerships, information and public safety: Community policing in a time of terror. Policing: An International Journal of Police Strategies \& Management, 25(3), 530-542.

Manning, P. K. (1978). The police: Mandate, strategies, and appearances. In P. K. Manning \& J. V. Maanen (Eds.), Policing: A view from the street (7-32). Santa Monica: Goodyear Publishing Company.

Mastrofski, S. D. (1999). Policing for people. Ideas in American Policing. Washington DC: The Police Foundation. Retrieved from https://www.policefoundation.org/wp-content/uploads/2015/06/Mastrofski-1999-Policing-For-People.pdf.

Mastrofski, S. D., Jonathan-Zamir, T., Moyal, S., \& Willis, J. J. (2016). Predicting procedural justice in police-citizen encounters. Criminal Justice and Behavior, 43(1), 119-139.

Mawby, R. C. (2002). Policing images: Policing, communication and legitimacy. Cullompton: Willan Publishing. Retrieved from http://site.ebrary.com/lib/natl/Doc?id=10750545.

Mawby, R. C. (2012). Models of policing. In T. Newburn (Ed.), Handbook of policing (17-46). London: Routledge.

Mazerolle, L., Bennett, S., Davis, J., Sargeant, E., \& Manning, M. (2013). Legitimacy in policing: A systematic review. (Campbell Systematic Reviews 2013/1). Oslo: The Campbell Collaboration.

Meares, T. L. (2012). The good cop: Knowing the difference between lawful or effective policing and rightful policing and why it matters. William \& Mary Law Revew, 54(6), 1865-1886.

Meyer, J. W., \& Rowan, B. (1977). Institutionalized organizations: Formal structure as myth and ceremony. American Journal of Sociology, 83(2), 340-363.

Moravcová, E. (2016). Willingness to cooperate with the police in four central European countries. European Journal on Criminal Policy and Research, 22(1), 171-187.

Murphy, K., Bradford, B., \& Jackson, J. (2016). Motivating compliance behavior among offenders: Procedural justice or deterrence? Criminal Justice and Behavior, 43(1), 102-118.

Nix, J., Wolfe, S. E., Rojek, J., \& Kaminski, R. J. (2015). Trust in the police: The influence of procedural justice and perceived collective efficacy. Crime \& Delinquency, 61(4), 610-640.

Palthe, J. (2014). Regulative, normative, and cognitive elements of organizations: Implications for managing change. Management and Organizational Studies, 1(2), 59-66.

Papachristos, A. V., Meares, T. L., \& Fagan, J. (2012). Why do criminals obey the law? The influence of legitimacy and social networks on active gun offenders. The Journal of Criminal Law and Criminology, 102(2), 397-440.

Peršak, N. (2014). Beyond procedural justice: Some neglected aspects of legitimacy of criminal law, policy and justice. In N. Peršak (Ed.). Legitimacy and trust in criminal law, policy, and justice: Norms, procedures, outcomes (1-12). Farnham: Ashgate Publishing.

Piquero, A. R., Fagan, J., Mulvey, E. P., Steinberg, L., \& Odgers, C. (2005). Developmental trajectories of legal socialization among serious adolescent offenders. The Journal of Criminal Law \& Criminology, 96(1), 267-298.

Ponsaers, P. (2015). Is legitimacy police property? In G. Meško \& J. Tankebe (Eds.), Trust and legitimacy in criminal justice (93-110). Springer International Publishing.

Reisig, M. D., \& Meško, G. (2009). Procedural justice, legitimacy, and prisoner misconduct. Psychology, Crime and Law, 15(1), 41-59.

Reisig, M. D., Wolfe, S. E., \& Holtfreter, K. (2011). Legal cynicism, legitimacy, and criminal offending: The nonconfounding effect of low self-control. Criminal Justice and Behavior, 38(12), 1265-1279.

Reisig, M. D., Tankebe, J., \& Meško, G. (2012). Procedural justice, police legitimacy, and public cooperation with the police among young Slovene adults. Varstvoslovje, 14(2), 147-164.

Rosanvallon, P. (2008). Counter-democracy: Politics in an age of distrust. Cambridge University Press. 
Sillince, J. A., \& Brown, A. D. (2009). Multiple organizational identities and legitimacy: The rhetoric of police websites. Human Relations, 62(12), 1829-1856.

Skogan, W. G. (2006). Asymmetry in the impact of encounters with police. Policing \& Society, 16(02), 99-126.

Suchman, M. C. (1995). Managing legitimacy: Strategic and institutional approaches. Academy of Management Review, 20(3), 571-610.

Tankebe, J. (2009). Public cooperation with the police in Ghana: Does procedural fairness matter? Criminology, 47(4), 1265-1293.

Tankebe, J. (2013). Viewing things differently: The dimensions of public perceptions of police legitimacy. Criminology, 51(1), 103-135.

Tankebe, J., Reisig, M. D., \& Wang, X. (2016). A multidimensional model of police legitimacy: A crosscultural assessment. Law and Human Behavior, 40(1), 11-52.

Trinkner, R., \& Cohn, E. S. (2014). Putting the "social" back in legal socialization: Procedural justice, legitimacy, and cynicism in legal and nonlegal authorities. Law and Human Behavior, 38(6), 602-617.

Trinkner, R., \& Tyler, T. R. (2016). Legal socialization: Coercion versus consent in an era of mistrust. Annual Review of Law and Social Science, 12, 417-439.

Tyler, T. R. (2004). Enhancing police legitimacy. The Annals of the American Academy of Political and Social Science, 593(1), 84-99.

Tyler, T. R. (2006a). Why people obey the law. Princeton University Press.

Tyler, T. R. (2006b). Psychological perspectives on legitimacy and legitimation. Annual Review of Psychology, 57, 375-400.

Tyler, T. R., \& Huo, Y. (2002). Trust in the law: Encouraging public cooperation with the police and courts. New York: Russell Sage Foundation.

Tyler, T. R., \& Fagan, J. (2008). Legitimacy and cooperation: Why do people help the police fight crime in their communities. Ohio State Journal of Criminal Law, 231(6), 231-275.

Tyler, T. R., Fagan, J., \& Geller, A. (2014). Street stops and police legitimacy: Teachable moments in young urban men's legal socialization. Journal of Empirical Legal Studies, 11(4), 751-785.

Vaughan, B. (2007). The provision of policing and the problem of pluralism. Theoretical Criminology, 11(3), 347-366.

Weber, M. (1964). The theory of social and economic organization. New York: Free Press of Glencoe.

Weber, M. (1972). Wirtschaft und Gesellschaft: Grundriss der verstehenden Soziologie: Studienausgabe. Tübingen: J. C. B. Mohr (Paul Siebeck).

Weigand, F. (2015). Investigating the role of legitimacy in the political order of conflict-torn spaces. (Security in Transition: Working Paper Series No. 4). London: London School of Economics. Retrieved from http://www.securityintransition.org/wp-content/uploads/2015/04/Legitimacy-in-the-PoliticalOrder-of-Conflict-torn-Spaces.pdf.

Wolfe, S. E. (2011). The effect of low self-control on perceived police legitimacy. Journal of Criminal Justice, 39(1), 67-74.

Wolfe, S. E., McLean, K., \& Pratt, T. C. (2017). I learned it by watching you: Legal socialization and the intergenerational transmission of legitimacy attitudes. British Journal of Criminology, 57(5), 1123-1143. 